\title{
Evaluation of Pollination by Honeybee (Apis Mellifera L.) on Canola (Brassica Napus L.) Produce
}

\author{
Asif Razzaq ${ }^{1}$, Khalida Hamid Abbasi ${ }^{1}$, Muhammad Jamal ${ }^{1}$, Asad Aslam², Kamil Malik ${ }^{2}$ and Muhammad \\ Arshad Ullah*3 \\ ${ }^{1}$ Beekeeping and Hill Fruit Pests Research, Pakistan \\ ${ }^{2}$ Ayub Agricultural Research Institute, Pakistan \\ ${ }^{3}$ National Agricultural Research Center, Pakistan
}

*Corresponding author: Muhammad Arshad Ullah, National Agricultural Research Center, Islamabad, Pakistan

\section{ARTICLE INFO}

Received: 幽 November 01, 2019

Published: 慧 November 08, 2019

Citation: Asif Razzaq, Khalida Hamid Abbasi, Muhammad Jamal, Asad Aslam, Kamil Malik, Muhammad Arshad Ullah. Evaluation of Pollination by Honeybee (Apis Mellifera L.) on Canola (Brassica Napus L.) Produce. Biomed J Sci \& Tech Res 22(4)-2019. BJSTR. MS.ID.003785.

Keywords: Honeybee; Pollination; Canola; Seed Yield

\section{ABSTRACT}

In order to quantify the response of honeybee (Apis mellifera L.) on canola seed yield, an experiment was conducted at Beekeeping and Hill Fruit Pests Research, Station Rawalpindi during 2016-17, in complete randomized block design with two treatments (i. Plants caged with honeybees ii. Plants caged without honeybees) with three replications each. Numbers of pods per plant, seeds per plant and seeds weight per 100 pods were measured in ten randomly harvested plants. The results showed significant increase in all the plant parameters caged with bees as compared to the plants without bees (control). Number of pods plant -1 and number No. of seeds plant -1 with pollination were 67 and828 while without pollination was 47 and 626 . The Seed weight 100 pods -1 (gm) with pollination was $4.42(\mathrm{gm})$ and without pollination was 3.53 (gm), respectively. It is concluded from the experiment that role of honeybee visitation to the canola flowers is important for pollination and increasing seed yield.

\section{Introduction}

Pollination is a most important ecosystem service provided by insects, resulting in sustainability and continuity of the ecosystem. Nearly $75 \%$ of the main crop species of the world rely on pollinators for fruit and seed set Klein et al. [1]. Pollinators contribute 35\% to global food volume and play a key role in supplying vital nutrients for human subsistence Klein et al. [1,2]. Crop-plant species vary significantly in their pollination requirements and, hence, their dependence on pollinating insects Morse and Calderone [3]. Pakistan is spending millions of dollars on the import of edible oil, which is a major drain on the foreign exchange reserves of the country Shahzad et al. [4]. The indigenous oil production of the country could not match the growing demand of population. The edible oil consumption was 2.764 million tons of which 0.857 million tons (31\%) came from local resources and 1.907 million tons (69\%) were imported (Anonymous, 2006). Oilseed crops rapeseed and mustards contribute $21 \%$ towards national oil production but the quality of oil is low due to erucic acid and glucosinolates production. Brassica napus L. is one of the two cultivars of rapeseed, while the other is Brassica compestris L. The oil from the seeds of these cultivars is fit for human consumption because low level of erucic acid.

Canola (Brassica napus L.) is considered to be self-compatible Eisikowitch [5], yet a certain degree of self-incompatibility is known. However, there is some conflict over the need for insect pollination. Some reporters claim that the presence of honeybees makes little or no difference in the amount of seed produced Williams [6]. Others have reported greater seed yield when honeybees were used for pollination Fries et al. [7]. Those reports may be resulted because of different varieties used, different ecological conditions and type of experiment carried out. Canada is the largest producer of canola in the world. Each year around 300,000 colonies of honeybees (half the colonies in Canada) contribute to the 12.6 million tonnes of open pollinated canola oil seed while about 80,000 colonies (approximately $12 \%$ of the total colonies) are exclusively dedicated 
for pollination of highly specialized hybrid seed canola industry. This hybrid seed industry is dependent on honeybees for precise pollen transfer of specific genetic lines. The average rental fee per hive is $\$ 120$ Canadian Honey Council [8]. Rape and mustard group of crops contribute about $16 \%$ of the domestic edible oil but their area is continuously decreasing during last 24 years. These have registered reduction of $46.0 \%$ in area and $23 \%$ in production. One of the major reasons for trends in area is the direct competition of rape seed mustard with wheat and winter fodder (Oilseeds Development strategy, 1995).

The other main problem of seed production of canola is pollination and fertilization of flowers. The most important missing link is the low density of pollinator's population including honeybee per unit area. The indiscriminate use of pesticides has declined pollinator's population to great extent. The Honeybee, Apis mellifera $L_{\text {., }}$ is of great economic importance in terms of increased yield and quality of commercially grown insect pollinated and also assists self-pollinated crops in the world Free [5]. In Pakistan use of bees, except honeybees in few cases, for pollination is still missing dimension in crop production. Apis mellifera is the only most abundant ecologically important introduced pollinator and is mostly managed for honey production. However, it is not so active during inclement weather which is very common at the time of early blooming period of fruit trees like apricot, almond pear, and apple. Therefore, there is enormous scope of improving the pollination of crops by designing and implementing strategies to manage economically important insect pollinator's especially native bees for seed and fruit production in agricultural ecosystem. This study was designed to examine the role of managed honeybee Api smellifera L. pollinator in increasing seed yield of canola crop. In addition, the research described in this study aimed to improve the understanding of the use of managed honeybee Apis mellifera L.colonies in cultivated crop pollination. The findings of this research will therefore contribute to the definition of general guidelines to maintain or improve canola crop pollination.

\section{Materials and Methods}

The experiment was conducted on canola crop var. PARC in the field area of Beekeeping and Hill Fruit Pests Research, Station Rawalpindi during Rabi Season 2016-17. The experiment was arranged in a randomized complete block design (RCBD) with two treatments and three replications each. The plot size was 12 $\mathrm{m} 2$. Before commencement of flowering i.e. second fortnight of December 2016, twelve cages of $(2 \times 2 \times 1 \mathrm{~m})$ made up of fine muslin cloth covering ten plants each were placed in the field. For the six cages (T1), approximately 500-600 worker honeybees of Apis mellifera $L$. were introduced in nucleus hives which were placed in the cages on iron stand nailed on wooden pegs dipped in already used diesel oil above the ground level to save the hives from rain, water and termites attack. Some sterilized pebbles were put in plastic bowls for easy access of bees to water source. It eliminated the chance of dipping of bees while sucking water. Water bowls were replaced twice a week to avoid water contamination with fungus etc.

For the other six cages i.e. Control (T2), no pollinators were allowed to enter. The flowering was completed by the end of March 2017 and crop was harvested by 15th April 2017. The number of pods formed in each plant from each cage was counted and after that 100 pods were randomly selected from both treatments and number of seeds developed in them were counted as well. The pods developed were dried naturally; their seed yield (gm) was calculated by rubbing the dried pods and taking the seeds out. EndNote statistical programme ver. 15.0 was used to analyze the data. Comparisons between means were made using the Least Significant Difference (LSD) at $\mathrm{p}<0.05$.

\section{Result and Discussion}

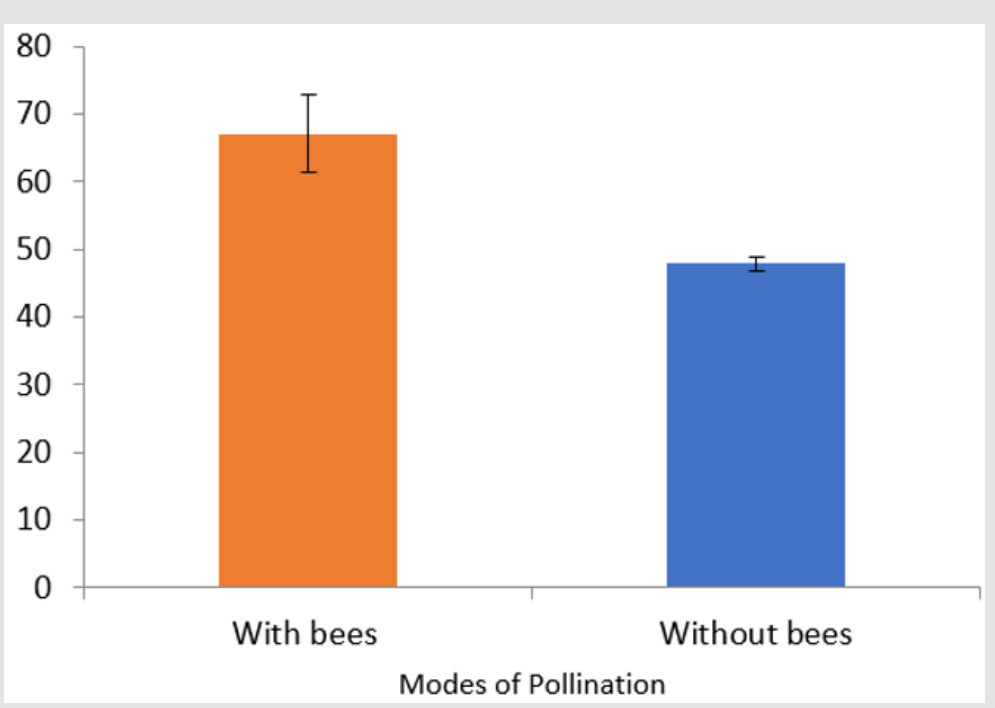

Figure 1: The mean number of pods per plant developed in plants caged with bees and without bees. 
The numbers of pods per plant developed were found to be significantly different for the treatments i.e. with and without bees (Two Way ANOVA, F $(2,8)=41.84, \mathrm{P}<0.001$ ) but no difference was found between the replicates (Two Way ANOVA, F $(3,8)=3.72$, P > $0.001)$. More pods developed in the plants with bees $(67.1 \pm 5.75$; Mean \pm SE), as compared to the plants without bees (47.91 \pm 1.06 Mean \pm SE) (Figure 1). The results of the reported study into the effect of pollination on yield of the examined canola crop can be compared with findings of other authors. Most of these confirmed an increased seed yield in plants available to pollinating insects compared to those under cover, e.g. by $16 \%$ in Australian studies Manning et al. [9], by 20-24 \% Jablonski et al. [10] and by over $50 \%$ in Czech Republic experiments Kamler [11]. The number of seeds per plantdeveloped within the pods with bees and without bees were 828.83 \pm 19.77 (Mean \pm SE) and $626.34 \pm 17.87$ (Mean \pm SE), respectively (Figure 2). The results were compared and significant difference was found between the treatments (Two Way ANOVA, F $(2,8)=237.47, \mathrm{P}<0.001)$ (Figure 2)

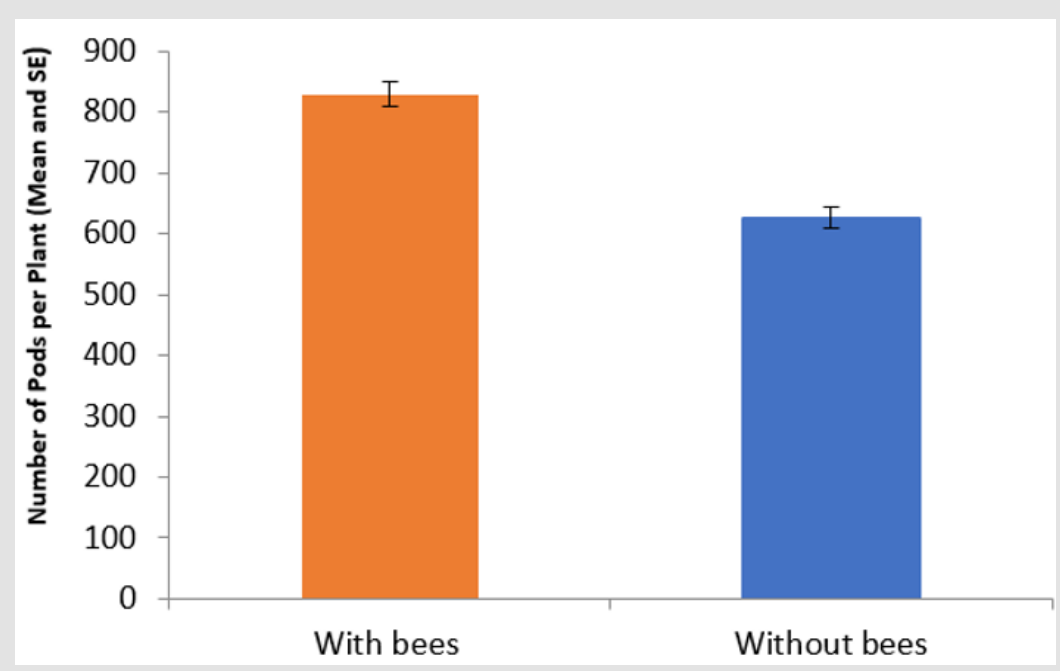

Figure 2: The mean number of seeds developed per plant in plants caged with bees and without bees.

The seeds were taken out and seed yield (gm) for 100 pods analyzed for treatments as well as replicates. We found a highly significant difference for treatments (Two Way ANOVA, F $(2,8)$ $=65.57, \mathrm{P}<0.001$ ) but no difference for the replicates (Two Way ANOVA, $F(3,8)=0.81, P>0.001)$. The mean weight of seed 100 pods -1 (gm) for with bees and without bee's treatment was $4.42 \pm 0.16$ (Mean $\pm \mathrm{SE}$ ) and 3.53 \pm 0.15 (Mean $\pm \mathrm{SE}$ ) respectively (Figure 3 ). A key role of pollinating insects has also been reported in male sterile lines and hybrid cultivars where without pollinators the seed yield appeared to be 3- 4 times lower than under conditions of free access of flowers to pollinating insects Koltowski [12]. In the light of above mentioned reports the results obtained in this study on pods and seed yield confirm the positive role of pollinating insects. However, despite the statistically confirmed, better yield for this cultivar and the significance of such differences could not be proven for all the cultivars, which have been observed by some other researchers who were not always able to statistically confirm the significance of beneficial impact of pollinating insects Mesquida et al. [13]. In conclusion, it may be stated that in the presence of the pollinating insects, the cultivar assayed in this study is capable of setting more pods, number of seeds and high seed weight which ultimately resulted in considerable increase in the seed yield [14].

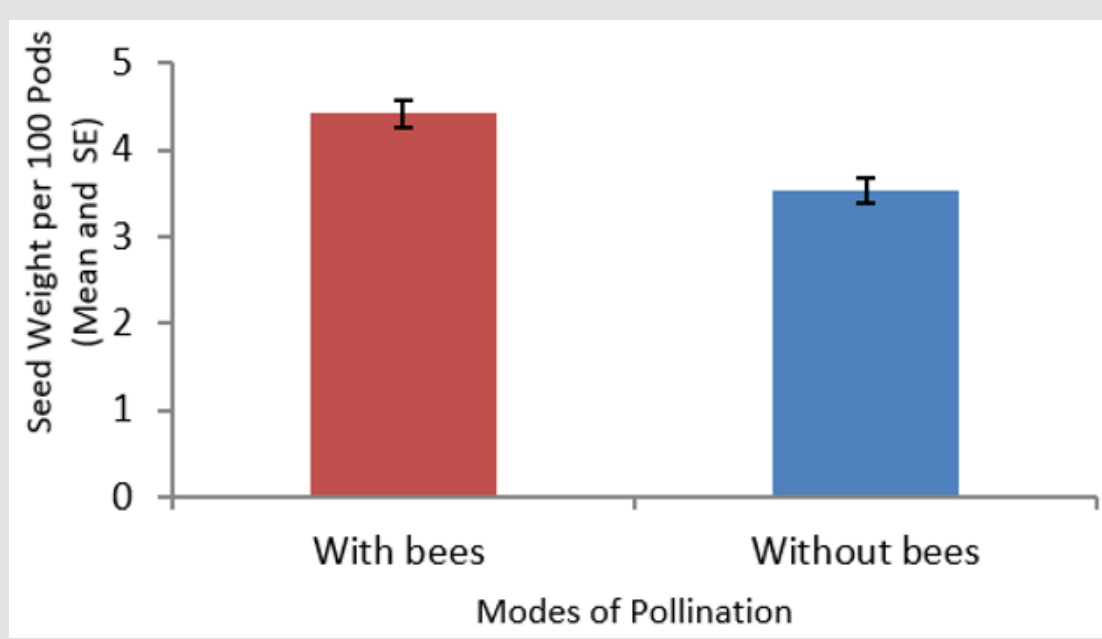

Figure 3: Seed weight per 100 podsin plants caged with bees and without bees. 


\section{References}

1. Klein AM, Vaissiere BE, Cane JH, Steffan Dewenter I, Cunninghan SA, et al. (2007) Importance of pollinators in changing landscapes for world crops. Proc Roy Soc B 274(1608): 303-313.

2. Gallai N, Salles JN, Settele J, Vaissiere BE (2008) Economic valuation of the vulnerability of world agriculture confronted with pollinator decline. Ecol Econ.

3. Morse R, Calderone NW (2000) The value of honeybees as pollinators of US Crops in 2000. Bee Cult 128: 1-15.

4. Shahzad MA, Rashid M (2006) Determination of pollen viability and role of honeybees Apiscerana in the pollination of sunflower CMS lines in isolated tunnels. Pak Entomol 28: 69-72.

5. Eisikowitch D (1981) Some aspects of pollination of oil seed rape (Brassica napus L.). J Agric Sci 96: 321-326. In Free JB (Eds.). (1993) Insect pollination of crops ( $2^{\text {nd }}$ Edn.) Acad Press, London-New York, USA, pp. 172-180.

6. Williams IH (1985) The pollination of Swedish rape (Brassica napus L.) Bee World 6: 16-22.

7. Fries I, Stark J (1983) Measuring the importance of honeybees in rape seed production. J Apic Res 22: 272-276.

ISSN: 2574-1241

DOI: 10.26717/BJSTR.2019.22.003785

Muhammad Arshad Ullah. Biomed J Sci \& Tech Res

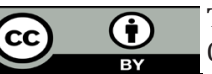

his work is licensed under Creative Commons Attribution 4.0 License

Submission Link: https://biomedres.us/submit-manuscript.php
8. (2009) Canadian Honey Council. Overview of the Canadian Apiculture Industry. Committee on Commodity Problems, Inter-governmental Group of Oils Seeds, Oils and Fats.

9. Manning R, Boland J (2000) A preliminary investigation into honeybee (Apismellifera) pollination of canola (Brassica napuscv Karoo). Aust J Experi Agric 40(3): 439-442.

10. Jablonski B, Skowrone J, Szklanowska K (1985) Bee keeping value, pollination and yields of low erucic acid winter rape seed cultivars. Pszczeln Zesz Nauk 39: 339-358.

11. Kamler F (1983) The response of selected winter rape cultivars to the pollination by honeybees. Rostlinnavyroba 29: 225-234.

12. Koltowski Z (2001) Bee keeping value and pollination requirements of double improved cultivars of spring rapeseed (Brassica napus $L$. varoleifera Metzger f. annuaThell.). J Apic Sci 45: 69-84.

13. Mesquida J, Renard M, Pierre JS (1988) Rapeseed (Brassica napus L.) productivity: The effect of honeybees (Apismellifera L.) and different pollination conditions in cage and field tests. Apidologie 19: 51-72.

14.(2006) Economic Survey of Pakistan.2005-06. Ministry of Finance, Government of Pakistan. pp. 11-16.

$\begin{array}{ll}\text { BIOMEDICAL } & \text { Assets of Publishing with us } \\ \text { RESEARCHES } & \text { - Global archiving of articles } \\ & \text { - Immediate, unrestricted online access } \\ & \text { - Rigorous Peer Review Process } \\ & \text { - Anttps://biomedres.us/ }\end{array}$

